\title{
Effect of Varieties, Depth and Methods of Planting on Growth, Yield Attributes, Yield and Economics of Rice
}

\author{
J.P. Mehra ${ }^{1}$, D.K. Malviya ${ }^{2}$, S.K. Singh ${ }^{1} *$, B.R. Baraiya ${ }^{2}$, V.B. Upadhyay ${ }^{2}$, \\ A. Gautam ${ }^{2}$, M.K. Gupta ${ }^{1}$ and Dhanraj Patel ${ }^{1}$ \\ ${ }^{1}$ Department of Agronomy, Institute of Agricultural Sciences, BHU, \\ Varanasi, U.P. 221005, India \\ ${ }^{2}$ Department of Agronomy, College of Agriculture J.N.K.V.V., Jabalpur (M.P.) 482 004, India \\ *Corresponding author
}

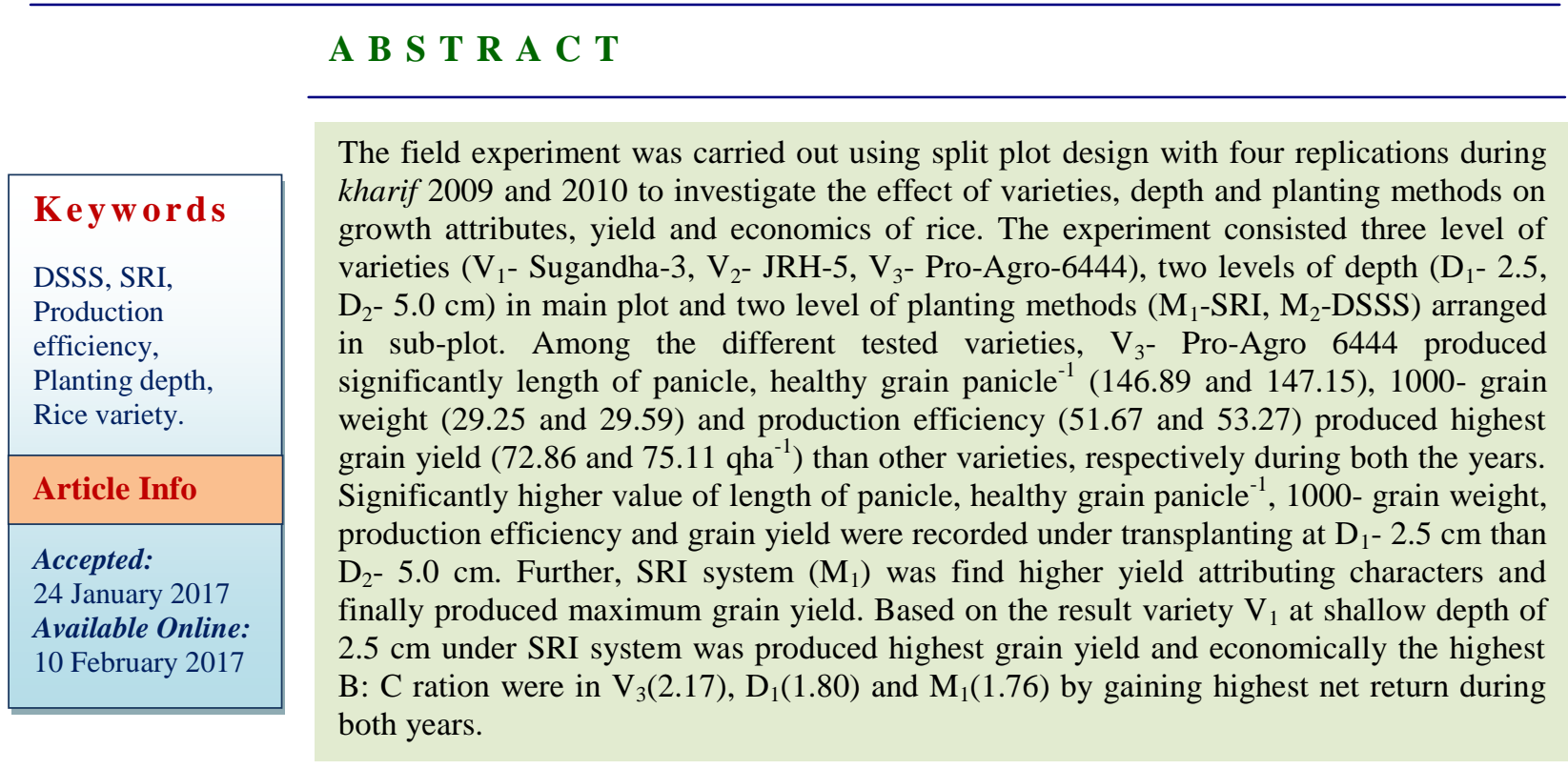

\section{Introduction}

Rice (Oryza sativa L.) is an important staple food crop of India, contributing $45 \%$ to the total food grain production. Hence, it is extensively grown in Eastern, Northern and Southern states of the country. In India rice is grown under diverse agro-ecological condition such as irrigated (19.6 million hectares), rainfed upland (7.1 million hectares), lowland (16.0 million hectares) and deep water (1.5 million hectares) (Moorthy and Mishra, 2004). It is widely grown in south eastern part of the country covering an area of 56.08 million hectares with an annual production of 92.6 million tonnes. India rank first in respect of area 44.50 million ha second in production 102.75 million tonne, only after China, but the productivity of rice is very low only 2.20 tonne $\mathrm{ha}^{-1}$ (Anonymous, 2012), which is quite low as compared to other rice growing countries like Japan (6.8 t/ha), Korea (6.1 $\left.\mathrm{t} \mathrm{ha}^{-1}\right)$, china $\left(5.9 \mathrm{t} \mathrm{ha}^{-1}\right)$ and Indonesia (4.3t ha $\left.^{-1}\right)$. Madhya Pradesh covers 1.76 million hectares with an annual production of 1.87 million tonnes and contributes 3.26 per cent of national hectare age with an average productivity of $2.06 \mathrm{t} \mathrm{ha}{ }^{-1}$. Among the 
different agronomic practices, planting management, depth of planting and planting methods play a vital role in achieving higher yield levels of hybrid and inbred rice. It is because the proper distributions of crop plant per unit area and efficient utilization of available resources as well as environment. In M.P. mostly rice is grown under direct seeding either dry broadcast after receiving first flush of shower or wet seeding of sprouted seeds in the puddle soil, which severely suffers from weeds resulting in very low yields. However, direct seeding of rice have several advantages i.e. saves labour, faster and easier planting, timely sowing, less drudgery, early crop maturity by $7-10$ days, less water requirement, high tolerance to water deficit often high yield, low production cost and more profit, better soil physical condition for succeeding crops and less methane emission (Balasubramanian and Hill, 2002). Further looking on the intensification in limited field, the system of rice intensification (SRI) has been highly emphasized to maximize the production of rice.

Careful transplanting of young seedlings at a wider spacing under SRI cultivation, ensures more root growth. Through appropriate water management strategies under SRI the field is kept moist and not flooded. Working of rotary weeder churns the soil and provides greater aeration which helps in buildup of enormous microbial growth, thereby enhancement of nutrient supply to root which ultimately result in healthy plant growth and higher yields at lower costs. System of Rice Intensification (SRI) is a alternative practice to solve the water crisis and as a methodology for increasing the productivity of irrigated rice by changing the management of plant, soil, water and nutrients (Natarajan et al., 2008). While, hybrid rice over inbred cultivation produce about $14-28 \%$ higher grain yield and distinct in growth and development phases particularly during the early growth stages, owing to their hybrid vigour, (Siddiq, 1993), extensive root system, greater sink size and great carbohydrate translocation from vegetative part to spikelets (Song et al., 1990). Keeping these in view, the present research was under taken to varieties, depth and methods of planting on growth, yield attributes, yield and economics of rice.

\section{Materials and Methods}

The field experiment was conducted in SPD design during kharif 2009 and 2010 at Krishi Nagar Farm, Adhartal, Department of Agronomy, Jawaharlal Nehru Krishi Vishwavidyalaya, Jabalpur, Madhya Pradesh. The experiment consisted of three levels of variety $\left(\mathrm{V}_{1}\right.$ : Sugandha-3, $\mathrm{V}_{2}$ : JRH-5, $\mathrm{V}_{3}$ : ProAgro 6444), two levels of depth ( $\mathrm{D}_{1}: 2.5 \mathrm{~cm}$, $\mathrm{D}_{2}: 5.0 \mathrm{~cm}$ ) and two level of planting method $\left(\mathrm{M}_{1}\right.$ : SRI, $\mathrm{M}_{2}$ : DSSS $)$.

The soil of experimental field was sandy clay loam in texture, medium in organic carbon $(0.68 \%)$, low in available nitrogen $(256 \mathrm{~kg}$ ha $\left.{ }^{1}\right)$ and phosphorus (7.99 kg ha-1), but high in potassium $\left(295 \mathrm{~kg} \mathrm{ha}^{-1}\right)$. The soil was nearly neutral in $\mathrm{pH}$ (7.5) and concentration of soluble salts $\left(0.32 \mathrm{ds} \mathrm{m}^{-2}\right)$ had below harmful limit. In respect of biological properties, it was normal in total bacterial count $(30.56 \mathrm{x}$ $10^{5} \mathrm{cfu} \mathrm{g}^{-1}$ soil) by Thronton's, (1930) and total fungi $\left(20.50 \times 10^{3} \mathrm{cfu} \mathrm{gm}^{-1}\right.$ soil $)$ and total actinomycetes $\left(65.90 \times 10^{3} \mathrm{cfu} \mathrm{gm}^{-1}\right.$ soil) by adopting techniques of Rao (1988).

In preparation of experimental treatment, three separate nursery beds each of $5.0 \mathrm{~m} \mathrm{x}$ $1.5 \mathrm{~m}$ dimension were prepared. The nursery beds were raised at height of $20 \mathrm{~cm}$ by spreading the loose soils on surface of bed, which were collected from the both sides of nursery beds in length direction. Uniformly spread of $25 \mathrm{~kg} \mathrm{FYM} \mathrm{bed}{ }^{-1}$ on the surface of nursery beds and then, it's well mixed in soil. 
Healthy seeds of varieties Sugandha-3, JRH-5 and Pro-Agro 6444 were treated with thirum (a) $3 \mathrm{~g} \mathrm{~kg}^{-1}$ of seeds before sowing in nursery beds on June 29 and July 12 during 2009 and 2010, respectively sown in rows $10 \mathrm{~cm}$ apart by covered with mixture of dried FYM and soil to obtain desirable age of seedling for transplanting as per treatment. A basal dose of well decomposed FYM (10 $\left.\mathrm{tha}^{-1}\right)$ was applied before transplanting/sowing and full dose of $50 \mathrm{~kg} \mathrm{P}_{2} \mathrm{O}_{5} \mathrm{ha}^{-1}$ and $30 \mathrm{~kg} \quad \mathrm{~K}_{2} \mathrm{O}$ ha $^{-1}$ was applied through single super phosphate and muriate of potash respectively at the time of puddling. As regards the nitrogen $\left(70 \mathrm{~kg} \mathrm{ha}^{-1}\right)$ $20 \% \mathrm{~N}$ was applied after $7 \mathrm{DAT} / \mathrm{DAS}, 50 \% \mathrm{~N}$ at 20-25 DAT/DAS and the remaining 30\% N at 50-55 DAT/DAS to all the plots in both the years.

For planting in the method of DSSS, the healthy selected seeds of three varieties viz; 'Sugandha-3', 'JRH-5' and 'Pro-Agro 6444' soaked for 24 hours in normal water and drain the water and incubate the seed in a gunny bag for about 4-6 hours of facilitate just sprouting and easy handling. After this, water drained the sprouted seeds of three varieties were treated carefully with thirum @ $3 \mathrm{~g} \mathrm{~kg}^{-1}$ seed before sowing@ @wo seeds hill ${ }^{-1}$ and transplanting of 12 days old seedling @ one seedling hill $^{-1}$ in SRI method, were direct seeded/ transplanted by manually at planting geometry of $20 \mathrm{~cm} \mathrm{x} 20 \mathrm{~cm}$ at depths of 2.5 and $5.0 \mathrm{~cm}$ in puddle field as per treatments during both year of experimentation.

Data on dry matter were recorded on 5 random places in each plot and plant biomass taken from these places to ensure the increase in biomass production overtime. Leaf area index (LAI) was recorded by using the Laser Area Metre crop growth rate (CGR) and relative growth rate (RGR) was calculated as per suggested by Watson (1952). Net assimilation rate (NAR) was also calculated as per Nichiporovich (1967). The economic parameters (gross returns, net returns and benefit: cost ratio) were worked out on the basis of prevailing market prices of inputs and outputs. Production efficiency $\left(\mathrm{kg} \mathrm{ha}^{-1} \mathrm{day}^{-1}\right)$ was worked out by dividing the total duration of crop (days). The data were analyzed by using the 'Analysis of Variance Technique' as per the procedures described by Snedecor and Cochron (1967). The treatment means were compared at $5 \%$ level of significance.

\section{Results and Discussion}

\section{Performance of varieties}

The leaf area index, dry matter of plant hill ${ }^{-1}$, crop grow rate (except first year) and net assimilation ratio was significantly influence by the varieties of rice (Table-1) with different level of depth and methods of transplanting. The dry matter of plant hill ${ }^{-1}$ was recorded significantly higher with variety $\mathrm{V}_{3}$ (Pro-Agro 6444) with per cent increase of (7.9 and 9.3, 7.3 and 9.2) over $\mathrm{V}_{2}(\mathrm{JRH}-5)$ and $\mathrm{V}_{1}$ (Sugandha-3) at harvest, respectively during both the year.

Similarly significant record noticed in leaf area index which was (4.37 and 4.30) maximum in comparison to other two variety. While, the CGR value declined at maturity stage over their preceding stage and was significantly higher with noted variety. Where, the net assimilation ration value was higher with $\mathrm{V}_{1}$ and lower in $\mathrm{V}_{3}$, it may be due to all leaves of plants at early stage have sufficient expose for synthesizing the carbohydrates through the photosynthesis but over lapping the canopy of plant leaves in advanced growth stage reduced the rate (Hon'e et al., 2003). Among the different tested varieties, variety $\mathrm{V}_{3}$ (Pro-Agro-6444) produced significantly higher number of effective tiller (6.8 and 6.92), healthy grain panicle $^{-1}$ (147.89 and 147.15), test weight (29.23 and 29.59), production efficiency 
(51.67 and 53.27), straw yield (16.60 and $\left.17.27 \mathrm{t} \mathrm{ha}^{-1}\right)$ and grain yield (7.28 and $7.51 \mathrm{t}$ $\mathrm{ha}^{-1}$ ) than other varieties, it was also remaining at par with variety $\mathrm{V}_{2}$ in respect of effective tiller (during second year) and straw yield with value of 15.51 and $15.56 \mathrm{t} / \mathrm{ha}$ ) during both year of experimentation and thus the $\mathrm{V}_{3}$ showed their valuing effect of gross return (69.6 Rs. ha ${ }^{-1}$ ), net return (37.7 Rs. ha $\left.{ }^{1}\right)$ and $\mathrm{B}$ : $\mathrm{C}$ ratio (2:17) was maximum over remaining two varieties in experimentation. The greater LAI value of plants resulted into higher photosynthetic activity, which ultimately increased the dry matter accumulation by plants at maturity confirmed by Linguing and Aijiug (2004). The crop growth rate gradually increased with crop age and reached its peak during fifty to seventy days of crop age and thereafter decline gradually as crop proceeded towards maturity (Jayanti et al., 2015). The grain yield of rice directly correlated to the number of effective tillers unit area $^{-1}$, number of grains panicle ${ }^{-1}$, test weight and fertile grain panicle ${ }^{-1}$ and straw yield directly related to growth parameters (Choudhary et al., 2009).

\section{Effect of planting depth}

Shallow depth of planting produced significantly more dry matter accumulation hill $^{-1}$ and leaf area index (during second year) with value of $(64.24$ and $64.25,3.89)$ for both year, respectively during investigation. However, their effect was non- significant but maximum recorded in crop growth rate, relative growth rate and lower in net assimilation rate. The effect of depth on length of panicle, healthy grain panicle ${ }^{-1}$, test weight and grain yield in value of (27.16 and 26.8, 135.50 and 135.77, 27.15 and 27.97), respectively over $\mathrm{D}_{2}(5.00 \mathrm{~cm})$. production efficiency was also higher with $D_{1}$ which caused to resulted highest economics and $\mathrm{B}: \mathrm{C}$ ratio. While effective tillers hill ${ }^{-1}$ was nonsignificantly higher than $\mathrm{D}_{2}$. It may be due to the increased active vegetative growth period thereby increased leaf area index which are responsible to manufacture higher food through photosynthesis for the growth and development of plants reported by Azhiri et al., (2005) and Hossain et al., (2003). Significantly higher values of yield attributing characters under shallow depth of planting than deeper planting depth viewed by Zhao et al., (1999).

\section{Effect of planting method}

The dry matter accumulation hill ${ }^{-1}$, leaf area index (except first year) and yield attributing character were significantly affected by methods of planting. Among the different planting methods, $\mathrm{M}_{1}$ (System of rice intensification) had proved the most optimum and appropriate method in value of (3.0 and 2.9 per cent) higher grain yield compared to $\mathrm{M}_{2}$ (direct seeding of sprouted seed), respectively during both the years. However, the maximum result in value of (13.61 and $\left.12.15 \mathrm{~g} \mathrm{~m}^{-2} \mathrm{day}^{-1}\right)$ in CGR, (6.52 and 6.61) in effective tiller/hill during both year, $\left(0.01 \mathrm{~g} \mathrm{~g}^{-}\right.$ ${ }^{1}$ day $^{-1}$ ) in RGR during first year recorded in $\mathrm{M}_{2}$ but were non- significant. Moreover, length of panicle (26.81 and 26.58), healthy grain panicle $^{-1}$ (134.64 and 135.03), 1000grain weight (27.28 and 27.42), grain yield (5.89 and $6.10 \mathrm{t} \mathrm{ha}^{-1}$ ) and straw yield (14.37 and $14.71 \mathrm{t} \mathrm{ha}^{-1}$ ) were recorded under $\mathrm{M}_{1}$ over $\mathrm{M}_{2}$, which was showed higher in production efficiency during both of the year. In economically, $\mathrm{M}_{1}$ effect was also higher by $\mathrm{B}$ : $C$ ratio (1.76) over $M_{2}$ during investigation. There was increase in the plant height and number of tillers, when rice was grown in SRI plots compared to farmer's practice reported by Verma et al., (2015). The maximum yield of grain and straw under SRI may be due to the maximum plant growth parameters by maximum translocation of photosynthates (Xu et al., 2005 and Thiyagarajan, 2007). 
Table.1 Growth characters of rice as influenced by varieties, depth and methods of planting (Pooled data of 2 years)

\begin{tabular}{|c|c|c|c|c|c|c|c|c|c|c|}
\hline \multirow{2}{*}{ Treatment } & \multicolumn{2}{|c|}{$\mathrm{DMA} \mathrm{hIIl}^{-1}(\mathrm{~g})$} & \multicolumn{2}{|c|}{ LAI } & \multicolumn{2}{|c|}{ CGR $\left(\mathrm{g} \mathrm{m}^{-2} \mathrm{day}^{-1}\right)$} & \multicolumn{2}{|c|}{ RGR $\left(\mathrm{g} \mathrm{g}^{-1} \mathrm{day}^{-1}\right)$} & \multicolumn{2}{|c|}{ NAR $\left(\mathrm{g} \mathrm{m}^{-2} \mathrm{day}^{-1}\right)$} \\
\hline & 2009 & 2010 & 2009 & 2010 & 2009 & 2010 & 2009 & 2010 & 2009 & 2010 \\
\hline \multicolumn{11}{|l|}{ Varieties } \\
\hline $\mathrm{V}_{1}$ :'Sugandha-3' & 59.9 & 60.01 & 2.39 & 2.64 & 14.19 & 11.81 & 0.011 & 0.008 & 0.0137 & 0.0109 \\
\hline $\mathrm{V}_{2}:^{\prime} \mathrm{JRH}-5^{\prime}$ & 60.98 & 61.07 & 2.84 & 3.25 & 12.85 & 11.56 & 0.009 & 0.009 & 0.0096 & 0.0083 \\
\hline 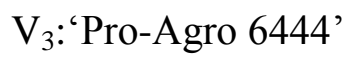 & 65.85 & 65.57 & 4.37 & 4.3 & 13.69 & 12.76 & 0.009 & 0.009 & 0.0072 & 0.0066 \\
\hline $\mathrm{CD}(\mathrm{P}=0.05)$ & 0.58 & 0.56 & 0.28 & 0.42 & NS & 0.85 & $\mathrm{NS}$ & $\mathrm{NS}$ & 0.0017 & 0.0012 \\
\hline \multicolumn{11}{|l|}{ Depths } \\
\hline $\mathrm{D}_{1}: 2.5 \mathrm{~cm}$ & 64.29 & 64.25 & 3.31 & 3.89 & 13.9 & 11.96 & 0.009 & 0.008 & 0.0101 & 0.0076 \\
\hline $\mathrm{D}_{2}: 5.0 \mathrm{~cm}$ & 60.19 & 60.18 & 3.09 & 2.9 & 13.25 & 12.12 & 0.01 & 0.009 & 0.0102 & 0.0095 \\
\hline $\mathrm{CD}(\mathrm{P}=0.05)$ & 0.47 & 0.46 & NS & 0.34 & NS & NS & NS & NS & NS & 0.001 \\
\hline Methods & & & & & & & & & & \\
\hline $\mathrm{M}_{1:} \mathrm{SRI}$ & 62.98 & 62.99 & 3.2 & 3.61 & 13.54 & 11.93 & 0.009 & 0.008 & 0.01 & 0.008 \\
\hline $\mathrm{M}_{2}: \mathrm{DSSS}$ & 61.51 & 61.44 & 3.21 & 3.18 & 13.61 & 12.15 & 0.01 & 0.009 & 0.0103 & 0.0091 \\
\hline $\mathrm{CD}(\mathrm{P}=0.05)$ & 0.55 & 0.55 & NS & 0.31 & NS & NS & NS & 0.001 & NS & 0.0009 \\
\hline
\end{tabular}

SRI=System of rice intensification DSSS=Direct Seeding of sprouted seeds 
Table.2 Yield and its attributes of rice as influenced by varieties, depth and methods of planting

\begin{tabular}{|c|c|c|c|c|c|c|c|c|c|c|c|c|c|c|}
\hline \multirow[t]{2}{*}{ Treatment } & \multicolumn{2}{|c|}{$\begin{array}{l}\text { Effective } \\
\text { tillers } \\
\text { hill }^{-1}\end{array}$} & \multicolumn{2}{|c|}{$\begin{array}{l}\text { Length of } \\
\text { panicle } \\
(\mathrm{cm})\end{array}$} & \multicolumn{2}{|c|}{$\begin{array}{l}\text { Healthy grains } \\
\text { panicle }^{-1}\end{array}$} & \multicolumn{2}{|c|}{$\begin{array}{l}\text { 1000-grain } \\
\text { weight }(\mathrm{g})\end{array}$} & \multicolumn{2}{|c|}{$\begin{array}{c}\text { Production } \\
\text { efficiency } \\
\left(\mathrm{Kg} \mathrm{ha}^{-1} \text { day }^{-}\right. \\
\left.{ }_{1}\right)\end{array}$} & \multicolumn{2}{|c|}{$\begin{array}{l}\text { Grain yield } \\
\quad\left(\mathrm{t} \mathrm{ha}^{-1}\right)\end{array}$} & \multicolumn{2}{|c|}{$\begin{array}{c}\text { Straw yield }( \\
\left.\mathrm{ha}^{-1}\right)\end{array}$} \\
\hline & 2009 & 010 & 009 & 2010 & 2009 & 2010 & 2009 & 2010 & 2009 & 2010 & 2009 & 2010 & 2009 & 2010 \\
\hline \multicolumn{15}{|l|}{ Varieties } \\
\hline $\mathrm{V}_{1}$ :'Sugandha-3' & 5.94 & 6.1 & 26.49 & 26.85 & 121.44 & 121.76 & 23.13 & 23.53 & 33.35 & 34.95 & 4.16 & 4.36 & 10.42 & 10.92 \\
\hline $\mathrm{V}_{2}:$ 'JRH-5' & 6.51 & 6.66 & 26.19 & 27.06 & 2.14 & 13 & 27.69 & 28. & 50.5 & 52.41 & 5.96 & 6.18 & 15.51 & 15.56 \\
\hline $\mathrm{V}_{3}:^{\prime}$ Pro-Agro 6444' & 6.8 & 6.92 & 25.54 & 24.73 & 146.89 & 147.15 & 29.25 & 29.59 & 51.67 & 53.27 & 7.28 & 7.51 & 16.60 & 17.27 \\
\hline $\begin{array}{c}\mathrm{CD}(\mathrm{P}=0.05) \\
\text { Depths }\end{array}$ & 0.27 & 0.31 & 0.51 & 0.4 & 1.43 & 1.13 & 0.38 & 0.49 & - & - & 0.81 & 0.81 & 14.4 & 2.14 \\
\hline $\mathrm{D}_{1}: 2.5 \mathrm{~cm}$ & 6.41 & 6.44 & 27.16 & 26.8 & 135.50 & 135.77 & 27.15 & 27.97 & 46.69 & 49.54 & 5.97 & 6.19 & 14.53 & 14.91 \\
\hline $\mathrm{D}_{2}: 5.0 \mathrm{~cm}$ & 6.42 & 6.68 & 24.99 & 25.63 & 131.48 & 131.95 & 26.23 & 26.13 & 44.01 & 46.8 & 5.63 & 5.85 & 13.82 & 14.26 \\
\hline $\begin{array}{c}\mathrm{CD}(\mathrm{P}=0.05) \\
\text { Methods }\end{array}$ & NS & NS & 0.42 & 0.33 & 1.17 & 0.92 & 0.31 & 0.40 & - & - & 0.66 & 0.66 & NS & 1.75 \\
\hline $\mathrm{M}_{1:} \mathrm{SRI}$ & 6.32 & 6.51 & 26.81 & 26.58 & 134.64 & 135.03 & 27.28 & 27.42 & 44.98 & 47.72 & 5.89 & 6.10 & 14.37 & 14.71 \\
\hline $\mathrm{M}_{2}$ : DSSS & 6.52 & 6.61 & 25.34 & 25.85 & 132.34 & 132.68 & 26.09 & 26.68 & 45.75 & 48.25 & 5.71 & 5.93 & 13.98 & 14.45 \\
\hline $\mathrm{CD}(\mathrm{P}=0.05)$ & NS & NS & 0.52 & 0.35 & 0.63 & 0.83 & 0.27 & 0.40 & - & - & 0.07 & 0.07 & NS & 0.19 \\
\hline
\end{tabular}

$\mathrm{SRI}=$ System of rice intensification DSSS=Direct Seeding of sprouted seeds 
Table.3 Interaction effect of planting depths x planting methods on grain yield(t ha-1) and depths $\mathrm{x}$ varieties on straw yield(t ha-1) during second years

\begin{tabular}{|c|c|c|}
\hline \multirow{2}{*}{ Methods } & \multicolumn{2}{|c|}{ Depths } \\
\hline & At $D_{1}(2.5 \mathrm{~cm})$ & At $\mathrm{D}_{2}(5.0 \mathrm{~cm})$ \\
\hline $\mathrm{M}_{1}: \mathrm{SRI}$ & 6.29 & 5.92 \\
\hline $\mathrm{M}_{2}: \mathrm{DSSS}$ & 6.09 & 5.77 \\
\hline $\mathrm{CD}(\mathrm{P}=0.05)$ & Methods x depths & 1.03 \\
\hline \multicolumn{3}{|l|}{ Varieties } \\
\hline $\mathrm{V}_{1}$ : 'Sugandha-3' & 11.42 & 10.41 \\
\hline $\mathrm{V}_{2}:$ 'JRH-5' & 15.71 & 15.40 \\
\hline $\mathrm{V}_{3}$ : 'Pro-Agro 6444' & 17.58 & 16.96 \\
\hline $\mathrm{CD}(\mathrm{P}=0.05)$ & Varieties $\mathrm{x}$ depths & 3.03 \\
\hline
\end{tabular}

SRI= System of rice intensification DSSS $=$ Direct seeding of sprouted seeds

Table.4 Effect of varieties, depths and methods of planting on economics of rice ( Pooled data of 2 years)

\begin{tabular}{|c|c|c|c|c|}
\hline Treatment & $\begin{array}{l}\text { Cost of cultivation } \\
\left(\mathbf{X} \mathbf{1 0}^{\mathbf{3}} ₹ \mathbf{h a}^{-1}\right)\end{array}$ & Gross returns $\left(\mathrm{X} 10^{3} ₹ \mathrm{ha}^{-1}\right)$ & Net returns $\left(\mathrm{X} 10^{3}\right.$ ₹ $\left.\mathrm{ha}^{-1}\right)$ & Benefit: cost ratio \\
\hline \multicolumn{5}{|l|}{ Varieties } \\
\hline $\mathrm{V}_{1}$ : 'Sugandha-3' & 31.9 & 40.5 & 8.6 & 1.27 \\
\hline $\mathrm{V}_{2}:{ }^{\prime} \mathrm{JRH}-5$ ' & 31.9 & 57.8 & 25.9 & 1.81 \\
\hline $\mathrm{V}_{3}$ : 'Pro-Agro 6444' & 31.9 & 69.6 & 37.7 & 2.17 \\
\hline \multicolumn{5}{|l|}{ Depths } \\
\hline $\mathrm{D}_{1}: 2.5 \mathrm{~cm}$ & 31.9 & 57.6 & 25.7 & 1.80 \\
\hline $\mathrm{D}_{2}: 5.0 \mathrm{~cm}$ & 31.9 & 54.4 & 22.5 & 1.70 \\
\hline \multicolumn{5}{|l|}{ Methods } \\
\hline $\mathrm{M}_{1}: \mathrm{SRI}$ & 32.3 & 56.8 & 24.5 & 1.76 \\
\hline $\mathrm{M}_{2}: \mathrm{DSSS}$ & 31.5 & 55.2 & 23.6 & 1.74 \\
\hline
\end{tabular}

SRI=System of rice intensification, DSSS =Direct seeding of sprouted seeds 
Interaction effect of planting depth $\mathrm{x}$ planting method and varieties $x$ depth

The data (Table-3) on combined effect of planting depth was found significant on grain yield during 2010. The grain yield in $\mathrm{M}_{1}$ (SRI) at shallow depth of planting $\mathrm{D}_{1}(2.5 \mathrm{~cm})$ was found higher $(1.7 \%)$ followed by $\mathrm{M}_{2}$. The grain yield $(5.77 \mathrm{t} / \mathrm{ha})$ was found minimum on $\mathrm{M}_{2}$ with $\mathrm{D}_{2}$. Another interaction between variety with planting depth was found significant on the straw yield in 2010 (Table- 3). The $\mathrm{V}_{3}$ (Pro-Agro-6444) produced significantly higher straw yield $(3.66 \%)$ with $\left.\mathrm{D}_{1} 2.5 \mathrm{~cm}\right)$ and minimum straw yield was recorded under interaction with $\mathrm{V}_{1}$ (Sugandha-3) at $\mathrm{D}_{2}(5.00 \mathrm{~cm})$ of planting depth.

\section{References}

Anonymous. 2012. Agriculture statistics at the glance, Department of agriculture and co-operation, ministry of agriculture, Government of India, New Delhi.

Azhiri Sigari, T., Gines, H., Sebastian, L.S. and Wade, L. 2005. Seedling vigor of rice cultivars in response to seeding depth and soil moisture. Philippine $J$. Crop Sci., 30(1): 53-58.

Balasubramanian, V. and Hill, J.E. 2002. Direct seeding of rice in Asia: Emerging issues and strategic research need for $21^{\text {st }}$ century in direct seeding; Research strategies and opportunities in proceedings. International workshop in direct seeding in Asian rice system 25-28 January 2000, Bangkok, Thailand. Int. Rice Res. Institute, Los Banos Phillippines pp. 38.

Choudhary, R.L., Kumar, D. and Singh, N. 2009. System of rice intensification (SRI) and Plant Growth Producing Rhizobacteria (PGPR) effect on growth and yield of rice hybrids $.4^{\text {th }}$ WCCA, 4-
7 New Delhi Feb.2009, PP-208.

Hosaain, M.J., Hossain, M.A, Anwar, M.P., Sarkar, M.R.A., Mamun, A.A. 2003. Performance of BRRI Dhan 32 in SRI and conventional method and their mixed technology mixes. Pak. J. Agronomy, 2(4): 195-200.

Jayanti, K., Singh, S., Perween, S., Kumar, S., Pal, S. K., Thakur, R., 2015. Growth and Yield of aerobic rice hybrids under varying seed rate, The Ecoscan, 9(3\&4): 897-904.

Linguing, Z., and Aijing, M. 2004. Study on the constitution of LAI and stems and tillers and their relationship in early stage of high yielding population in rice. J. Yunnan Agri. Univ., 19(2): 179183.

Moorthy, B.T.S. and Mishra J.S. 2004. Rice ecosystems. Problems and their management. Indian Farming, 54(8): $39-45$.

Natrajan, S. 2008. 3rd National Symposium, SRI in India, policies, institutions and strategies for scaling- up, held at Tamil Nadu Agricultural University, Coimbatore, pp. 9-55.

Nichiporovich, A.A. 1967. Aims of research on photosynthesis of plants as a factor of production. (In) Photosynthesis of productive systems. Programme for Science, Translation, Jerusalam, Israel, pp. 3-36.

Rao, N.S. 1988. Biofertilizers in Agriculture. Oxford and IBH, Publishing Company Private Limited, New Delhi.

Siddiq, E.A. 1993. Rice production strategy for $21^{\text {st }}$ century. Oryza, 30(1): 180196.

Snedecor, G.W. and Cochran, W.G. 1967. Statistical methods. Oxford and IBH publ. Sixth Edu. Pp. 325-330.

Song, X., Agata, W. and Kawamistu, Y. 1990. Studies on dry matter and grain production of $F_{1}$ hybrid rice in China. Characteristics of grain production. 
Japan J. Crop Sci., 159: 29-33.

Thiyagarajan, T.M. 2007. SRI in Tamil Nadu current-Scenario. $\quad 2^{\text {nd }} \quad$ National Symposium on SRI $3^{\text {rd }}$ to $5^{\text {th }}$ Oct. 2007. Agartala, Tripura.India, PP-136-138.

Verma, V.K., Meena, R.N., Gautam, A., Gaurav, Tyagi, V. and Kumar, A. 2015. Effect of crop establishment method and different source of $\mathrm{Zn}$ on growth, yield and quality of rice (Oryza sativa 1.), The Ecoscan, 9(3\&4): 873-876.

Watson, D.J. 1952. Physiological basis of variation in yields. Advances in
Agronomy, 4: 101-145.

Xu-Feng, Ying., Ma. Jun., Wang Hezheng., Liu, Huiyuan, Huang, Qinglong, MawenBo and Ming, Dong Feng. 2005. Rice quality under the cultivation of SRI. Acta Agronomica Sinica, 31(5): 577-582.

Zhao, Zhichao, Takahashi, K. and Zhao, Z.C. 1999. Variation in emergence of rice sown at different depths. Japanese J. Crop Sci., 68(4): 501-507.

\section{How to cite this article:}

Mehra, J.P., D.K. Malviya, S.K. Singh, B.R. Baraiya, V.B. Upadhyay and Gautam, A. 2017. Effect of Varieties, Depth and Methods of Planting on Growth, Yield Attributes, Yield and Economics of Rice. Int.J.Curr.Microbiol.App.Sci. 6(2): 1750-1758. doi: http://dx.doi.org/10.20546/ijcmas.2017.602.196 